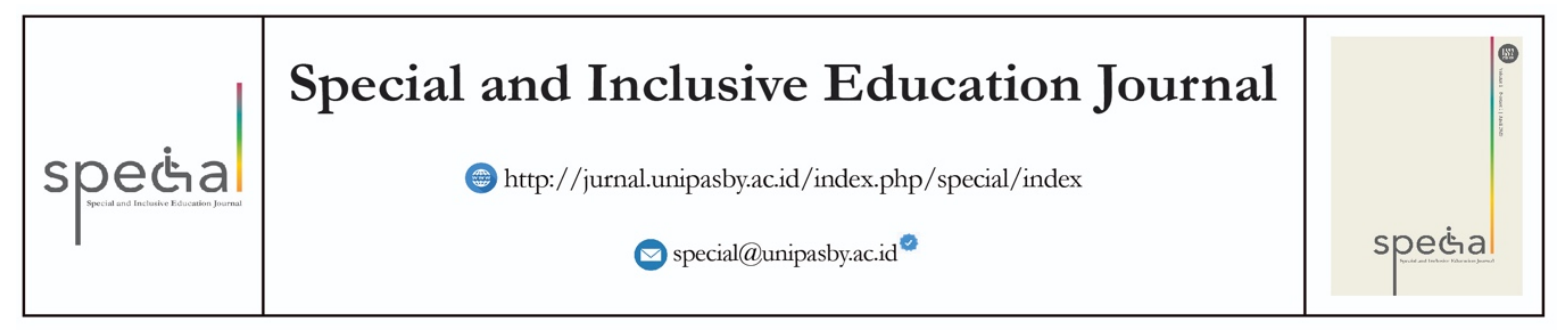

\title{
Studi Kasus Anak dengan Gangguan Bahasa Reseptif dan Ekspresif
}

\author{
Isabella Hasiana \\ isabella@unipasby.ac.id \\ Program Studi Pendidikan Anak Usia Dini - Universitas PGRI Adi Buana Surabaya \\ Dukuh Menanggal XII, Surabaya 60234 Jawa Timur, Indonesia
}

\begin{tabular}{l}
\hline Artikel Info \\
\hline Koresponden penulis : \\
Isabella Hasiana \\
isabella@,unipasby.ac.id \\
- Diterima 25 Maret 2020 \\
- Direview 29 Maret 2020 \\
- Disetujui 3 April 2020 \\
- Dipublikasi 29 April 2020 \\
\\
Kata Kunci: \\
Anak Dengan Gangguan \\
Bahasa Reseptif Dan \\
Ekspresif, Komunikasi, \\
Anak Usia Dini \\
\hline
\end{tabular}

\section{Keywords:}

Children with Receptive and Expressive Language

Disorders, Communication, Early Childhood

\begin{abstract}
Absstrak
Berbicara merupakan suatu kemampuan utama yang harus dimiliki oleh setiap individu untuk dapat berkomunikasi dengan orang lain. Banyak orangtua yang cenderung kurang memiliki kekhawatiran apabila anaknya belum lancar berbicara dibandingkan anak lain yang seusianya. Mereka menganggap bahwa keterlambatan bicara adalah sesuatu yang wajar, terutama jika ada anggota keluarga yang dahulu juga mengalami keterlambatan. Kenyataan di lapangan menunjukkan bahwa anak yang terlambat bicara dipengaruhi oleh lima faktor, yaitu adanya hambatan didalam pendengaran, hambatan perkembangan pada otak yang menguasai kemampuan oral-motor, masalah keturunan, masalah pembelajaran dan komunikasi dengan orangtua serta juga dapat dikarenakan faktor televisi. Penelitian ini merupakan penelitian yang menggunakan pendekatan kualitatif terhadap satu anak berusia 4 tahun sehingga dikatakan sebagai penelitian studi kasus. Analisis data yang dilakukan di dalam penelitian ini menggunakan tehnik trianggulasi. Hasil penelitian menyimpulkan bahwa gangguan bahasa yang dialami dikarenakan faktor televisi dan komunikasi sehari-hari yang dilakukan di dalam keluarga

Abstarct
Speaking is a major ability that must be possessed by every individual to
be able to communicate with others. Many parents tend to have fewer
worries if their children are not fluent in speaking compared to other
children their age. They assume that late talking is something natural,
especially if there are family members who were also experiencing delays
in the past. The reality on the ground shows that children who are late in
talking are influenced by five factors, namely the presence of obstacles in
hearing, developmental barriers in the brain that control oral-motor skills,
hereditary problems, learning problems, and communication with parents
and can also be due to television factors. This research is a study that uses
a qualitative approach to one 4-year-old child so it is said to be a case
study. Data analysis was performed in this study using triangulation
techniques. The results of the study concluded that language disorders
experienced were due to television and daily communication factors
carried out in the family
\end{abstract}




\section{PENDAHULUAN}

Belajar khususnya belajar berbicara adalah suatu proses yang tidak dapat lepas dari kehidupan manusia mulai dari usia 0 tahun sampai dewasa. Setiap individu akan mengalami proses yang disebut pembelajaran. Pembelajaran dapat dilakukan secara formal maupun non-formal. Pendidikan anak usia dini, yang paling penting untuk dilakukan adalah memberikan pondasi dasar bagi pembentukan kepribadian dan hal tersebut memiliki peranan penting yang akan menentukan perkembangan anak di masa depan. Sesuai dengan Undang-Undang No. 20 tahun 2003 tentang sistem pendidikan nasional Bab 1 pasal 1 ayat 2 yang menyatakan bahwa pendidikan anak usia dini (PAUD) adalah upaya pembinaan yang ditujukan untuk anak-anak sejak lahir hingga usia 6 tahun yang dilakukan melalui pemberian stimulasi pendidikan kepada membantu pertumbuhan dan perkembangan jasmani dan rohani sehingga anak memiliki kesiapan dalam memasuki pendidikan lebih lanjut. Dalam hal tersebut tentunya harus diimbangi dengan kematangan dalam aspek perkembangannya. Ini sangat penting karena akan mengetahui perkembangan pertumbuhan anak ketika akan memasuki dunia pendidikan sehingga nantinya tidak akan mengalami kesulitan di masa depan.

Sebagai orangtua tentu akan merasa bangga jika memiliki anak dengan perkembangan yang normal, khususnya dalam perkembangan kemampuan berbahasa. Namun pada kenyataannya, terdapat anak usia dini yang mengalami gangguan dalam berbahasa. Untuk itulah tujuan penelitian mendeskripsikan anak yang mengalami gangguan bahasa reseptif dan ekspresif. Kata "bahasa" pada dasarnya diartikan sebagai suatu sistem lambang bunyi yang arbitrer dan digunakan oleh individu di dalam suatu masyarakat untuk bekerjasama, berinteraksi dan melakukan identifikasi diri. Selain itu, bahasa juga diartikan sebagai percakapan atau perkataan yang baik antara dua orang atau lebih dengan maksud untuk menyampaikan dan menerima suatu informasi.

Pada anak usia dini perkembangan bahasa dikatakan sebagai suatu perubahan sistem lambang bunyi yang memiliki pengaruh terhadap kemampuan berbicara anak usia dini. Dengan kemampuan berbicara yang dimiliki, maka anak akan mampu untuk mengidentifikasi dirinya, serta berinteraksi dan bekerja sama dengan orang lain (Wiyani, 2014). Pada bayi yang baru lahir, tentu ia belum dapat untuk berbicara dengan orang lain. Bayi hanya bisa menangis untuk mendapatkan sesuatu yang diinginkannya. Seiring dengan bertambahnya usia, di usia enam hingga delapan bulan bayi mulai membuat suara prabicara yang sering dikenal dengan istilah celoteh. Setelah anak mulai berceloteh, maka ia akan menirukan ucapan dan beberapa gerakan dari orang lain di sekitarnya. Sebelum anak mencapai usia satu tahun, pada anak akan muncul tanda-tanda bahwa ia memahami instruksi sederhana yang diberikan, misalnya "mana hidung", "ke sini".

Pada saat anak berusia 12 hingga 18 bulan celotehan tersebut akan berkembang menjadi suatu ucapan atau perkataan yang dapat dipahami maknanya sampai anak berusia enam tahun dimana ia mulai mampu berbicara dengan kalimat yang sederhana, memiliki penguasaan kosa kata yang semakin meningkat, yaitu dalam kisaran 10.000 kata. Selain itu anak juga mulai dapat berbicara dengan menggunakan kalimat yang lebih tersusun dan memiliki kemampuan dalam melakukan komunikasi 
yang baik dengan orang lain (Wiyani, 2014). Perkembangan bahasa pada anak usia dini memiliki tiga fungsi, yaitu: (1). Bahasa memiliki fungsi sebagai alat untuk mengungkapkan pikiran dan perasaan anak. Hasil dari aktivitas berpikir anak, perasaan yang dialami oleh anak, akan diekspresikan dengan bahasa. Misalnya, “adek sedih mama marah”, “adek mau pergi main”. Hal ini menegaskan bahwa aspek berbahasa pada anak usia dini berkaitan dengan aspek perkembangan kognitif dan emosi; (2). Bahasa berfungsi sebagai alat bagi anak dalam berkomunikasi dengan orang lain. Sejak anak dilahirkan, ia sudah memiliki kemampuan untuk berkomunikasi dengan orang lain meskipun dengan menggunakan bahasa yang sangat sederhana, yaitu tangisan; (3). Bahasa juga memiliki fungsi sebagai alat yang digunakan oleh anak untuk hidup bersama dengan orang lain di sekitarnya. Pada dasarnya, manusia adalah makhluk sosial yang membutuhkan bantuan dari orang lain baik secara langsung maupun tidak langsung untuk memenuhi kebutuhan hidupnya, dan dalam pemenuhan kebutuhan tersebut menggunakan bahasa.

Sebelum anak dapat berbicara, awalnya ia akan mengeluarkan suara-suara yang bersifat sederhana lalu berkembang secara kompleks dan mengandung arti. Misalnya, saat bayi ia akan menangis (crying), mendekut (cooing), mengoceh (babling), lalu dapat menirukan berbagai kata yang didengarnya dari orangtua dan lingkungan sekitar. Kemampuan yang diawali dengan mengeluarkan suara seperti menangis, mendekut, mengoceh dan meniru kata-kata sebelum anak dapat berbicara dengan jelas sesuai artinya disebut dengan pre-linguistic speech (Wiyani:2014). Oleh sebab itu, seiring dengan semakin bertambahnya usia anak maka kemampuannya dalam berbicara juga akan berkembang. Untuk mengoptimalkan perkembangan bahasanya, maka perlu dilakukan pemberian stimulasi berupa pembelajaran bahasa bagi anak usia dini. Ada dua faktor yang berpengaruh dalam perkembangan bahasa anak, yaitu: 1). Faktor kematangan fisiologis. Perkembangan bahasa berkaitan dengan kematangan fisiologis atau secara fisik (physicological maturity) dan sistem syaraf pusat (central nervous system) dalam otak anak. Individu dibekali dan diberi kemampuan untuk berkomunikasi dan berbahasa sejak dari dalam kandungan, namun tentunya kemampuan tersebut tidak langsung berkembang secara sempurna. Diperlukan kematangan fisiologis yang baik dan pertumbuhan berbagai organ fisik berjalan dengan normal tanpa ada gangguan pada otak, sistem syaraf, tenggorokan, lidah, mulut, pharinc, atau sistem pernafasan. Hal ini dikarenakan, organ-organ tersebut mendukung perkembangan kemampuan seseoang dalam berbahasa maupun mengungkapkan berbagai pesan komunikasi dengan jelas sehingga dapat dipahami oleh orang lain.

Pengaruh yang ke dua dalam perkembangan bahasa anak adalah perkembangan sistem syaraf yang ada di dalam otak. Sistem syaraf pada janin yang masih berkembang di dalam kandungan terjadi dalam kurun waktu yang bersamaan dengan pembentukan berbagai organ eksternal janin pada masa tri wulan pertama kehamilan. Hal itu membuat otak sudah memiliki kemampuan untuk menerima stimulus eksternal yang diberikan dari lingkungan hidupnya. Sehingga setiap stimulus yang diterima oleh janin akan menjadi bahan-bahan jejak ingatan (traces of memory) dalam otak janin. Orangtua yang sering memberikan stimulus eksternal pada janin selama masih di dalam kandungan melalui bercerita, 
mendongeng, menyanyi, bahkan berkomunikasi akan membuat janin merasakan getaran-getaran bahwa ia disayangi oleh orangtuanya dan menimbulkan perasaan ikatan emosi yang kuat dengan orangtuanya.

Tabel 1 Perkembangan Bahasa Anak

\begin{tabular}{|c|c|}
\hline Usia & Perkembangan Bahasa \\
\hline $0-3$ bulan & $\begin{array}{l}\text { - Anak menangis } \\
\text { - Anak berteriak } \\
\text { - Anak bergumam }\end{array}$ \\
\hline 3-6 bulan & $\begin{array}{l}\text { - Anak akan mendengarkan ucapan orang lain } \\
\text { - Anak mulai mengoceh } \\
\text { - Anak akan tertawa atau tersenyum kepada orang yang mengajaknya berkomunikasi }\end{array}$ \\
\hline 6-9 bulan & $\begin{array}{l}\text { - Anak mulai menirukan ucapan } \\
\text { - Anak memberikan respon terhadap permainan cilukba } \\
\text { - Anak mulai mampu menunjuk benda dengan mengucapkan satu kata }\end{array}$ \\
\hline $9-12$ bulan & $\begin{array}{l}\text { - Anak mulai mampu mengucapkan dua kata untuk menyatakan keinginan } \\
\text { - Anak dapat menyatakan penolakan } \\
\text { - Anak dapat menyebut nama benda atau binatang }\end{array}$ \\
\hline $12-18$ bulan & $\begin{array}{l}\text { - Anak dapat mengucapkan kalimat yang terdiri daru dua kata } \\
\text { - Anak memberikan respon terhadap pertanyaan dengan jawaban "ya" atau "tidak" } \\
\text { - Anak dapat menunjukkan bagian tubuh yang ditanyakan } \\
\text { - Anak dapat memahami cerita pendek }\end{array}$ \\
\hline 18-24 bulan & $\begin{array}{l}\text { - Anak dapat menggunakan kata-kata sederhana untuk menyatakan keingintahuan } \\
\text { - Anak memberikan perhatian pada gambar-gambar dalam buku } \\
\text { - Anak mampu menjawab pertanyaan dengan kalimat pendek } \\
\text { - Anak dapat menyanyikan lagu sederhana }\end{array}$ \\
\hline $2-3$ tahun & $\begin{array}{l}\text { - Anak mulai hafal beberapa lagu sederhana } \\
\text { - Anak dapat memahami cerita/dongeng sederhana } \\
\text { - Anak mampu untuk menggunakan kata tanya dengan tepat (apa, siapa, bagaimana, } \\
\text { mengapa, di mana) }\end{array}$ \\
\hline 3-4 tahun & $\begin{array}{l}\text { - Anak dapat menyatakan keinginan dengan mengucapkan kalimat sederhana } \\
\text { - Anak mampu untuk menceritakan pengalaman yang dialami dengan cerita sederhana } \\
\text { - Anak dapat membaca cerita bergambar dalam buku dengan kata-kata sendiri } \\
\text { - Anak mulai memahami perintah yang mengandung } 2 \text { pengertian (misalnya, ambil buku } \\
\text { lalu berikan pada ibu) }\end{array}$ \\
\hline $4-5$ tahun & $\begin{array}{l}\text { - Anak dapat mengutarakan sesuatu hal kepada orang lain } \\
\text { - Anak mampu menyatakan alasan terhadap sesuatu yang diinginkan atau ketidaksetujuan } \\
\text { - Anak bisa mengenal perbendaharaan kata mengenai kata sifat (nakal, pelit, baik hati, } \\
\text { baik, jelek, dan lainnya) } \\
\text { - Anak dapat menceritakan kembali cerita/dongeng yang pernah didengarnya }\end{array}$ \\
\hline 5-6 tahun & $\begin{array}{l}\text { - Anak dapat menyusun kalimat sederhana ddalam struktur lengkap (pokok kalimat- } \\
\text { predikat-keterangan) } \\
\text { - Anak mulai terlibat dalam pemilihan dan memutuskan aktivitas yang akan dilakukan } \\
\text { bersama temannya } \\
\text { - Anak memiliki perbendaharaan kata lebih kaya dan lengkap untuk melakukan } \\
\text { komunikasi verbal. }\end{array}$ \\
\hline
\end{tabular}


Sekitar 1 dari 20 anak usia dini memiliki perkembangan bahasa yang terlambat dibandingkan anak lain seusianya sehingga memerlukan penanganan yang serius terkait dengan kegiatan pembelajaran bagi perkembangan bahasanya. Perlu menjadi kewaspadaan bagi orangtua maupun guru jika sampai pada usia 2 tahun hanya ada sedikit tanda-tanda yang ditunjukkan dari anak untuk melakukan komunikasi dengan mengacu pada tabel perkembangan bahasa diatas. Pada perkembangan bahasa ada yang dinamakan gangguan bahasa reseptif dan gangguan bahasa ekspresif. Gangguan bahasa reseptif diartikan sebagai kesulitan yang dialami oleh anak usia dini dalam menerima pesan atau informasi dari orang lain yang disampaikan melalui verbal atau suara meskipun sebenarnya ia sedikit mengerti dengan pesan yang disampaikan orang lain. Sedangkan definisi gangguan bahasa ekspresif yaitu kesulitan yang dialami oleh anak untuk mengungkapkan apa yang ingin mereka katakan dan anak mampu untuk memahami yang dikatakan oleh orang lain namun sulit baginya untuk mengungkapkan kembali dalam bentuk kalimat. Pada gangguan bahasa ekspresif, anak usia dini memiliki kesulitan untuk mengeskpresikan dirinya dalam berbicara. Pada dasanya anak sangat ingin berkomunikasi namun ia mengalami kesulitan untuk menemukan kata-kata yang tepat (Wiyani, 2014).

Ada gejala-gejala yang muncul dan dapat diamati apakah seorang anak usia dini memiliki gangguan bahasa reseptif dan gangguan bahasa ekspresif. Pada gangguan bahasa reseptif, gejala yang muncul, adalah: (a). Anak seperti tidak memperhatikan lawan bicaranya saat diajak berbicara; (b). Anak kurang memberikan respons maupun tanggapan saat dibacakan buku cerita oleh orang lain; (c). Anak tidak mampu untuk memahami suatu kata maupun kalimat yang rumit; (d). Anak tidak mampu untuk mengikuti instruksi secara lisan dengan baik. Sedangkan gejala yang muncul pada gangguan bahasa ekspresif, yaitu: (a). Anak sama sekali tidak mau berbicara; (b). Perbendaharaan kata yang dimiliki anak terbatas; (c). Anak sering membuat kesalahan dalam kosa kata; (d). Anak mengalami kesulitan dalam mengingat kata-kata atau membentuk kalimat yang panjang; (e). Anak memiliki kesulitan dalam pencapaian prestasi akademik dan komunikasi sosial, namun pemahaman anak terhadap bahasa relatif utuh; (f). Anak tidak mampu untuk memulai suatu percakapan; (g). Anak merasa sulit saat diminta untuk menceritakan kembali suatu cerita atau suatu peristiwa.

\section{METODE PENELITIAN}

Penelitian ini merupakan penelitian yang bersifat non-eksperimen, yaitu penelitian kasus (casestudies). Studi kasus adalah salah satu metode penelitian ilmu-ilmu sosial. Penggunaan penelitian studi kasus ini merupakan strategi yang lebih sesuai jika pertanyaan penelitian berkenaan dengan how atau why (Yin, 2008). Dalam penelitian ini, peneliti berkedudukan sebagai instrumen penelitian yang utama (Arikunto, 2010). Penentuan subyek penelitian bersumber dari informasi yang disampaikan oleh pihak sekolah, dimana hanya ada satu anak di dalam sekolah tersebut yang memiliki "keunikan" dibandingkan teman sekelasnya. Subyek merupakan anak usia empat tahun yang duduk dibangku TK A. Pengumpulan data menggunakan observasi dan wawancara yang dilakukan secara mendalam kepada orangtua dan guru kemudian melakukan analisa data menggunakan triangulasi. Triangulasi 
dapat dilakukan dengan dua cara, yaitu (1). Triangulasi dengan sumber yang sama tetapi dilakukan dengan cara atau metode yang berbeda dan (2). Triangulasi dilakukan dengan cara atau metode yang sama tetapi dengan sumber data yang berbeda (Arikunto, 2010). Dalam hal ini peneliti melakukan cara yang kedua. Yaitu dilakukan dengan cara atau metode yang sama namun sumber data berbeda. Penelitian ini mendapatkan sumber data selain dari anak, juga dari orang yang tinggal serumah dengan anak, dalam hal ini ibu dan nenek (ayah sudah meninggal). Sumber data juga didapatkan dari guru kelas anak

\section{HASIL DAN PEMBAHASAN}

Dari hasil observasi dan wawancara yang telah dilakukan, dari pihak sekolah (subyek informasi dengan inisial RY), mengatakan bahwa RY "berbeda" dibandingkan teman-teman sekelasnya. Sebelum masuk ke TK tersebut, ia sudah berpindah TK sebanyak dua kali. Hal ini dikarenakan, RY anak yang memerlukan perhatian dan bimbingan khusus dari pihak sekolah, namun di TK sebelumnya kurang mendapatkan perhatian.

Dalam kegiatan bermain, ia selalu sendirian tanpa teman dan juga tidak melakukan komunikasi dengan teman atau jikapun ada komunikasi, kata-kata yang diucapkan hanya sepotong-potong bahkan terkesan tanpa makna dan tidak bisa menyusun kata-kata tersebut menjadi satu kalimat utuh, misalnya: "Sepatu pakai" yang seharusnya "memakai sepatu", "Tidak CD ya, tunggu Mami” seharusnya "menonton CD nya nanti menunggu Mami datang", atau kalimat RY yang lainnya "Baju basah" seharusnya, "Baju saya basah Oma". Jika ingin sesuatu, RY menunjuk dengan tangan benda yang diinginkan, misalnya: RY ingin bermain gendang kecil pada waktu pelajaran, atau RY merasa kepanasan saat berada di dalam kelas, maka RY akan menunjuk kipas angin. Selain itu respon RY saat berkomunikasi dengan Oma juga dengan kata yang sepotong-potong. Contohnya, "RY, hari ini belajar apa?" reaksi dari RY, "garis" seharusnya respon yang muncul "hari ini belajar membuat garis."

Tidak hanya menjawab dengan kata sepotong-sepotong tetapi RY juga terkadang mengulangi pertanyaan yang diajukan kepadanya (echolalia). Misalnya: "RY sudah mandi belum?” Respon yang muncul, "sudah mandi belum". Reaksi RY tidak sesuai dengan pertanyaan yang ditanyakan. Saat Guru bertanya kepada RY, "RY mengapa terlambat”, Respon dari RY terkadang menjawab terkadang tidak. Jika menjawab, yang dikatakan RY, "terlambat” seharusnya "terlambat karena tukang becaknya terlambat datang menjemput."

Selain itu dari hasil amatan tentang capaian perkembangan bahasa anak, seperti disampaikan dalam tabel dibawah ini : 
Tabel 2 Capaian Aspek Perkembangan Anak

\begin{tabular}{|c|c|c|}
\hline $\begin{array}{l}\text { Aspek } \\
\text { Perkembangan }\end{array}$ & Indikator Ketercapaian & Hasil Amatan \\
\hline \multirow[t]{7}{*}{ Perkembangan bahasa } & $\begin{array}{l}\text { Menyebutkan berbagai } \\
\text { bunyi/suara tertentu }\end{array}$ & $\begin{array}{l}\text { anak mengenal dan mengetahui berbagai jenis } \\
\text { binatang yang ada dalam kehidupan sehari-hari, } \\
\text { namun untuk artikulasi kata dalam penyebutan } \\
\text { nama binatang tidak jelas dan terbalik-balik. } \\
\text { Misalnya menyebut "monyet", RY mengatakan } \\
\text { "nomet". }\end{array}$ \\
\hline & $\begin{array}{lll}\text { Menirukan } & \text { kembali } & 3-4 \\
\text { urutan kata } & & \\
\end{array}$ & $\begin{array}{l}\text { anak belum mampu untuk menyatakan sesuatu } \\
\text { dengan lengkap (3-4 kata) karena cenderung } \\
\text { mengulang kembali pertanyaan yang diajukan } \\
\text { kepada dirinya. Contoh: "RY hari ini makan apa?" } \\
\text { jawabannya, "Hari ini makan apa?" sampai } \\
\text { pertanyaan tersebut diulang 2-3 kali. }\end{array}$ \\
\hline & $\begin{array}{l}\text { Melakukan 2-3 perintah } \\
\text { secara sederhana }\end{array}$ & $\begin{array}{l}\text { Anak dapat mengerti dan melaksanakan } 2 \text { perintah } \\
\text { namun tidak secara bersamaan. Artinya perintah } \\
\text { tersebut harus diberikan secara satu persatu dulu. } \\
\text { Contoh: "RY letakkan buku ini di tengah meja dan } \\
\text { kembalikan pensil ke meja guru". Reaksi dari RY, } \\
\text { ia hanya mengembalikan pensilnya saja tanpa } \\
\text { bukunya. Jika diminta kembali, maka RY akan } \\
\text { melakukannya lagi. }\end{array}$ \\
\hline & $\begin{array}{l}\text { Mengajukan pertanyaan } \\
\text { lebih banyak "apa", } \\
\text { "kenapa", "dimana" }\end{array}$ & RY tidak pernah mengajukan pertanyaan apapun. \\
\hline & $\begin{array}{l}\text { Menyebutkan nama benda } \\
\text { dan fungsi }\end{array}$ & $\begin{array}{l}\text { RY mengetahui nama-nama benda yang } \\
\text { diketahuinya lewat CD namun untuk benda-benda } \\
\text { yang tidak pernah di ketahuinya dari CD, ia tidak } \\
\text { mengetahui nama benda dan fungsi benda itu. }\end{array}$ \\
\hline & $\begin{array}{l}\text { Dapat menyebutkan kata- } \\
\text { kata baru sesuai tema }\end{array}$ & $\begin{array}{l}\text { Anak dapat menyebutkan kata-kata baru sesuai } \\
\text { tema berdasarkan dari CD yang ditontonnya. }\end{array}$ \\
\hline & $\begin{array}{l}\text { Mengungkapkan keinginan } \\
\text { ("aku mau”), penolakan } \\
\text { ("tidak mau") dan } \\
\text { pendapatnya }\end{array}$ & $\begin{array}{l}\text { anak tidak dapat mengungkapkan keinginan, } \\
\text { penolakan maupun pendapatnya dengan kata-kata } \\
\text { yang biasa diucapkan oleh orang lain }\end{array}$ \\
\hline
\end{tabular}

Sumber: Kurikulum TK, Departemen Pendidikan Nasional (2004).

Dari tabel 2 di atas, RY diketahui mengalami gangguan bahasa reseptif dan gangguan bahasa ekspresif. Dalam hal ini ia mengalami kesulitan dalam melakukan komunikasi dengan orang lain yang umumnya menggunakan bahasa verbal. Namun dari kasus RY tersebut, ia lebih banyak menggunakan komunikasi dengan nonverbal. Jika orang lain tidak memahami apa yang disampaikannya, perilaku yang muncul adalah berteriak dan marah. Penyebab dari gangguan bahasa ini pada anak seringkali tidak diketahui, namun ada dugaan bahwa penyebabnya dapat terjadi karena faktor komunikasi dan faktor televisi. Latar belakang keluarga RY, bahwa ia sudah tidak memiliki ayah (meninggal dunia) saat RY masih dalam kandungan, yang menyebabka ibu mengalami depresi sehingga kurangnya asupan gizi yang diterima oleh janin. Selain itu, Ibu bekerja dan RY hanya berdua saja dengan nenek, dan dalam kesehariannya RY tidak pernah keluar rumah untuk bermain dengan teman sebayanya, dan hanya menonton CD dalam Bahasa Inggris. 
Komunikasi yang terjalin antara anak dengan orangtua ataupun teman sebayanya juga mempengaruhi kemampuan berbahasa anak. Jarang atau kurangnya komunikasi yang dijalin dapat menyebabkan anak mengalami gangguan bahasa ekspresif. Dalam permasalahan RY, ia tidak diperbolehkan untuk keluar rumah bergaul dengan anak tetangga seusianya. Selain itu, faktor televisi juga menjadi penyebab anak mengalami gangguan bahasa. Saat menonton televisi anak menjadi pendengar yang pasif. Anak memposisikan dirinya sebagai pihak yang menerima tanpa harus mencerna dan memproses informasi yang masuk. Jika hal tersebut berlangsung dalam waktu yang cukup panjang, maka sel-sel otak yang menyangkut kemampuan berbahasanya khususnya kemampuan berbicaranya dapat terhambat perkembangannya.

Menurut Musrifoh, (2008) pada anak usia TK atau pra-sekolah, perkembangan fonologisnya memang belum berkembang dengan sempurna, namun hampir semua yang dikatakan oleh orang lain anak dapat mengerti dan memahami. Kegiatan berbahasa yang menonjol pada anak-anak prasekolah yang sering dilakukan ialah menggunakan kalimat tanya. Meskipun telah dapat membuat kalimat dengan struktur yang baik, anak-anak sering mengajukan pertanyaan yang menunjukkan rasa ingin tahu anak akan suatu proses. Lebih lanjut Ronosulistyo dan Mulyadi (2008), menyatakan pada masamasa tertentu anak menunjukkan sikap selalu bertanya karena rasa ingin tahu yang besar. Sikap yang selalu ingin bertanya hendaknya mendapat respon yang positif dari orangtua, namun kondisi yang ada seringkali orang tua mengabaikan pertanyaan anak dengan merespon dingin dan tidak menjawab pertanyaan anak. Sikap orang tua yang demikian menyebabkan anak semakin bingung, menarik diri, kapok bertanya atau bahkan anak mencari jawaban ke orang lain.

Ketika usia taman kanak-kanak anak sudah menguasai hampir semua kaidah dasar gramatikal bahasanya. Anak sudah dapat membuat kalimat berita, kalimat tanya, dan sejumlah konstruksi lain. Menurut Baldie (dalam Ormrod, 2008), anak TK masih kesulitan dalam membuat kalimat pasif. Baru sekitar $80 \%$ dari anak usia tujuh setengah sampai delapan tahun dapat membuat kalimat pasif. Namun pada anak usia TK telah mempelajari hal-hal yang diluar kosakata dan tata bahasa. Anak-anak sudah dapat menggunakan bahasa dalam konteks sosial yang bermacam-macam. Pada saat memasuki usia Taman Kanak-Kanak, anak berada dalam rentang usia 4-6 tahun, karakteristik pekembangan bahasa anak dijelaskan sebagai berikut : (a). Meningkatnya perbendaharaan kata dari 4000 menjadi 6000 kata, menunjukkan perhatian yang lebih pada penggunaan abstrak, (b). Suka menyanyikan lagu-lagu sederhana; mengetahui banyak rima dan permainan jari, (c). Berani berbicara didepan kelompok walaupun sedikit enggan, suka bercerita tentang keluarga dan pengalaman kepada orang lain, (d). Menggunakan bentuk verbal untuk menyatakan banyak hal, suka menggoda orang lain, (e). Mengekspresikan emosi melalui gerakan wajah dan membaca bahasa tubuh orang lain; meniru perilaku anak yang lebih tua, (f). Mulai bisa membaca situasi, (g). Sering menggunakan struktur kalimat yang baik dan bereksperimen dengan konstruksi baru, (h). Mencoba berkomunikasi melebih perbendaharaan katanya, (i). Mempelajari perbendaharaan yang baru dengan cepat jika berhubungan 
dengan pengalaman sendiri, (j). Dapat menceritakan kembali empat atau lima langkah alur atau urutan dalam cerita (Hardman, 2002).

\section{KESIMPULAN}

Komunikasi merupakan hal yang penting dalam perkembangan anak. Seiring dengan perkembangan tersebut, maka diperlukan perhatian dari orangtua dan guru untuk mengoptimalkan perkembangan anak, khususnya perkembangan bahasa. Saat anak pada usia 2 tahun, masih belum mampu melakukan komunikasi, orangtua perlu memberikan perhatian yang serius agar permasalahan perkembangan bahasa anak dapat ditangani dengan baik. Faktor televisi juga menjadi pemicu anak mengalami gangguan dalam perkembangan bahasa terutama bila tidak ada pendampingan bagi anak usia dini dalam menyaksikan tayangan yang ada. Sehingga anak hanya menerima pesan tersebut dan menyerap tanpa ada komunikasi dua arah

\section{DAFTAR PUSTAKA}

Arikunto. 2010. Prosedur Penelitian Suatu Pendekatan Praktik. Rineka Cipta. Jakarta.

Michael L. Hardman. Human Exceptionality. Society, School, and Family. Seventh Edition

Ormrod., 2008. Psikologi Pendidikan Membantu Siswa Tumbuh dan Berkembang. Penerbit Erlangga.

Wiyani. 2014. Psikologi Perkembangan Anak Usia Dini Panduang bagi Orangtua dan Pendidik PAUD dalam Memahami serta Mendidik Anak Usia Dini. Penerbit Gava Media, Yogyakarta.

Wiyani. 2014. Buku Ajar Penanganan Anak Usia Dini Berkebutuhan Khusus. Penerbit Ar-Russ Media. Yogyakarta.

Yin. 2008. Studi Kasus Desain dan Metode. PT. RajaGrafindo Persada. Jakarta. 